\title{
Models and Critical Maneuvers for Road Vehicles
}

\author{
Kristoffer Lundahl
}

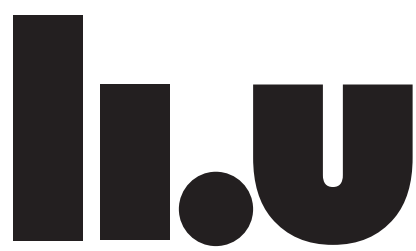

LINKÖPING UNIVERSITY

Department of Electrical Engineering

Linköping University

SE-581 83 Linköping, Sweden

Linköping 2016 
Linköping studies in science and technology. Dissertations, No. 1763

\section{Models and Critical Maneuvers for Road Vehicles}

Kristoffer Lundahl

ISBN 978-91-7685-771-7

ISSN 0345-7524

(C) 2016 Kristoffer Lundahl, unless otherwise noted. All rights reserved.

Kristoffer Lundahl

kristoffer.lundahl@liu.se

www.vehicular.isy.liu.se

Division of Vehicular Systems

Department of Electrical Engineering

Linköping University

SE-581 83 Linköping

Sweden

The cover: The cover illustration is based on an "accidental" photograph (he claims) taken at Mantorp Park by Viktor Svensson, here used with his permission.

Typeset with $\operatorname{AT} \mathrm{TEX}_{2} \varepsilon$

Printed by LiU-Tryck, Linköping, Sweden 2016 


\section{Abstract}

As manufacturers are pushing their research and development toward more simulation based and computer aided methods, vehicle dynamics modeling and simulation become more important than ever. The challenge lies in how to utilize the new technology to its fullest, delivering the best possible performance given certain objectives and current restrictions. Here, optimization methods in different forms can be a tremendous asset. However, the solution to an optimization problem will always rely on the problem formulation, where model validity plays a crucial role. The main emphasis in this thesis lies within methodology and analysis of optimal control oriented topics for safety-critical road-vehicle maneuvers. A crucial element here is the vehicle models. This is investigated as a first study, evaluating the degree to which different model configurations can represent the lateral vehicle dynamics in critical maneuvers, where it is shown that even the low-complexity models describe the most essential vehicle characteristics surprisingly well.

How to formulate the optimization problems and utilize optimal control tools is not obvious. Therefore, a methodology for road-vehicle maneuvering in safety-critical driving scenarios is presented, and used in evaluation studies of various vehicle model configurations and different road-surface conditions. It was found that the overall dynamics is described similarly for both the highand low-complexity models, as well as for various road-surface conditions.

If more information about the surroundings is available, the best control actions might differ from the ones in traditional safety systems. This is also studied, where the fundamental control strategies of classic electronic stability control is compared to the optimal strategy in a safety-critical scenario. It is concluded that the optimal braking strategy not only differs from the traditional strategies, but actually counteracts the fundamental intentions from which the traditional systems are based on.

In contrast to passenger cars, heavy trucks experience other characteristics due to the different geometric proportions. Rollover is one example, which has to be considered in critical maneuvering. Model configurations predicting this phenomenon are investigated using optimal control methods. The results show that the simple first go-to models have to be constrained very conservatively to prevent rollover in more rapid maneuvers.

In vehicle systems designed for path following, which has become a trending topic with the expanding area of automated driving, the requirements on vehicle modeling can be very high. These requirements ultimately depend on several various properties, where the path restrictions and path characteristics are very influential factors. The interplay between these path properties and the required model characteristics is here investigated. In situations where a smooth path is obtained, low-complexity models can suffice if path deviation tolerances are set accordingly. In more rapid and tricky maneuvers, however, vehicle properties such as yaw inertia are found to be important.

Several of the included studies indicate that vehicle models of lower complexity can describe the overall dynamics sufficiently in critical driving scenarios, which is a valuable observation for future development. 


\section{Populärvetenskaplig sammanfattning}

Allteftersom fordonsindustrin driver sin forskning och utveckling mot mer simuleringsbaserade metoder, så blir modellering och simulering kopplat till fordonsdynamik än viktigare. Fordonskomponenter, -egenskaper och -reglersystem utvärderas i allt större utsträckning i datorbaserade miljöer. En stor utmaning som uppstår här ligger i att utnyttja den nya tekniken till fullo, så att bästa möjliga prestanda uppnås med avseende på särskilda mål och begränsningar. För just detta ändamål kan optimeringsmetoder i olika former vara en stor tillgång. Även om optimeringsmetoder kan anses vara ett kraftfullt verktyg, så är lösningen till ett optimeringsproblem alltid helt beroende av problemformuleringen, det vill säga den målfunktion och de modellkonfigurationer som används. Således spelar modellernas giltighet en avgörande roll.

Två framstående ämnen som motiverar studier inom detta område är autonom körning och aktiv säkerhet. Autonom körning har på senare år gått från att vara ett futuristisk forskningsämne, till att betraktas som en tilltalande utvecklingsinriktning för transportsegmentet. Flera självkörande fordonskoncept har redan visats upp av forskningsinstitutioner och etablerade fordonstillverkare, vilket ger en glimt av vad transportsegmentet kan ha att erbjuda i framtiden. Dock, då delar av körmomenten automatiseras blir arbetsbelastningen på föraren betydligt mindre, vilket kan medföra att föraren blir understimulerad och då får en ökad responstid. Således ökar kraven på framtida säkerhetssystem drastiskt.

Den andra motiverande faktorn är de aktiva säkerhetssystemen. Kapaciteten hos elektroniska säkerhetssystem har under senare tid ökat snabbt, vilket erbjuder stora möjligheter för framtida system, där proaktiva och automatiserade reglersystem kan utvecklas. Men genom att lägga till mer automatiserade funktioner i fordonet, så ökar också kraven på säkerhetssystemet. Till exempel, om föraren inte är aktiv i körningen kan hans/hennes handlingar vid en plötslig säkerhetskritisk trafiksituation vara irrationella och direkt farliga.

Tyngdpunkten i denna avhandling ligger inom metodik och analys av ämnen inom optimal styrning kopplat till frågor som rör säkerhetskritiska fordonsmanövrar. En vital del här är de modeller som representerar fordonets egenskaper. Just detta undersöks i en första studie där relativt enkla fordonsmodellers förmåga att representera lateraldynamiken utvärderas i aggressiva och säkerhetskritiska manövrar. I den här studien framkommer det att även mindre komplexa modeller kan beskriva de viktigaste fordonsegenskaperna förvånansvärt bra, även för manövrar av mer aggressiv karaktär.

Det är inte självklart hur man bäst formulerar optimeringsproblem och utnyttjar de verktyg som finns tillgängliga för optimal styrning. En metodik för hur detta kan appliceras på olika kritiska körscenarier för vägfordon presenteras därför här. Denna metodik har även använts i utvärderingsstudier för olika konfigurationer av fordonsmodeller samt olika vägförhållanden i säkerhetskritiska körsituationer. Det konstaterades att de generella fordonsdynamiska egenskaperna beskrivs på liknande sätt både för modeller med hög och låg modellkomplexitet, medan styrsignaler och lågnivåvariabler kan skilja sig avsevärt.

Då information om den omgivande miljön eller situationen finns tillgänglig, är det högst troligt att de bäst lämpade reglerstrategierna skiljer sig från de som 
används i traditionella elektroniska säkerhetssystem. Detta har här studerats, där de grundläggande reglerstrategier från klassiska antisladdsystem jämförts med den optimala reglerstrategin i en säkerhetskritisk situation, då information om vägens avgränsningar är tillgänglig. Utifrån studien kan det konstateras att den optimala bromsstrategier inte bara skiljer sig från de traditionella strategierna, utan även motverkar de fundamentala avsikterna det traditionella systemet är designat efter.

I jämförelse med personbilar så uppstår andra karaktäristiska egenskaper som måste tas i beaktning då tunga lastbilar studeras. Ett sådant fenomen är vältning (eng. rollover), där den höga tyngdpunkten bidrar till att fordonet är benäget att välta. Modeller som predikterar detta undersöks med hjälp av optimal-styrningsmetoder för att generera kritiska manövrar. Resultaten visar att enkla modeller, som ofta gärna används i applikationer för just detta ändamål, måste begränsas väldigt restriktivt om de ska förhindra vältning även i hastigare manövrar.

Ett annat aktuellt ämne inom autonom körning är banföljning. I system avsedda för detta kan kraven på fordonsmodellerna behöva vara väldigt höga. Dessa krav beror ytterst på flera olika egenskaper, där banans begränsningar och karaktäristik är en mycket inflytelserik faktor. Det samspel som utgörs mellan dessa ban- och modellegenskaper undersöks här. Då en bana med relativt mjuk kurvatur erhålles, kan modeller med låg komplexitet räcka om toleranserna för banavvikelse sätts tillräckligt högt. Vid hastigare och kvickare manövrar blir dock andra fordonsegenskaper, som till exempel girtröghet, nödvändiga för att beskriva fordonets beteende tillräckligt noggrant.

Några av de viktigaste slutsatserna som lyfts fram i den här avhandlingen handlar om fordonsmodellering i applikationer kring optimal styrning, de fördelar och nackdelar som olika konfigurationer medför, samt några allmänna riktlinjer om var dessa modellkonfigurationer kan vara användbara. Exempelvis så indikerar flera av de ingående studierna att fordonsmodeller med lägre komplexitet, vilket ofta innebär att mindre beräkningskraft behövs, kan vara lämpliga för att beskriva övergripande dynamik, men bör användas mer varsamt vid prediktering av styrsignaler. 


\section{Acknowledgment}

This work has been carried out at the Division of Vehicular Systems at the Department of Electrical Engineering, Linköping University.

First and foremost I would like to thank a charismatic young man called Lars Nielsen, who many years ago took upon himself the challenge of guiding me through a full PhD. I am grateful for his support, enthusiasm, and patience as a supervisor. To the less appreciated (but certainly fascinating) qualities belongs his ability to fall asleep during one-on-one discussions. Jan Åslund is acknowledged for his much appreciated role as co-supervisor. I am also very thankful for Erik Frisk's role as semi co-supervisor and coauthor for the last papers. Karl Berntorp and Björn Olofsson are acknowledged for the cooperative work on optimal vehicle maneuvers, and Chih Feng Lee for the collaborations related to rollover.

Lars, Jan, Erik, and Björn, are all thankfully acknowledged for proofreading. All remaining garmmatical faults are left intentionally, to give the reader a slight sensation of superiority, and any form of pointing these out to the author will be met with a somewhat hostile response.

The research in this thesis has been financially supported by the iQMatic project, funded by the innovation and research program FFI/Vinnova, the Strategic Area for ICT research ELLIIT funded by the Swedish Government, and the Swedish Research Council within the Linnaeus Center CADICS. Thanks for contributing to my monthly paycheck.

My office-roommates throughout this time; Martin, Henrik, Peter, Mahdi, and Victor, are all acknowledged for contributing in their own best way to delaying this thesis as much as possible, especially DJ Martin for all the hilarious gangsta rap. Others at the division have also made great and successful efforts in this aspect, such as Vaheed teaching me to speak Farsi fluently and Xavi by enlighten us all about the importance of the Catalan independence.

Except for the people mentioned above, there are many others among friends, colleagues, and family, whose support I truly and deeply appreciate on a daily basis. And of course, a big thanks to Humle and Dumle, that is, the two heaviest dumbbells at Campushallen. Without these guys things would have been a disaster, or at least those guns would not shine as bright as they now do.

At the time of writing this, I have moved on to the real world, leaving the academic playground behind. However, somewhat to my surprise, I already realize I did take much for granted. The environment at Vehicular Systems was rather nice after all...

Kristoffer Lundahl

Gothenburg, May 2016 


\section{Contents}

1 Introduction $\quad 3$

1.1 Motivating Factors and Development Trends . . . . . . . . . . . 4

1.2 Optimal Control for Vehicle Maneuvers . . . . . . . . . . . . . 6

1.3 Summary of papers . . . . . . . . . . . . . . . . . 6

1.4 Outlook and Future Work . . . . . . . . . . . . . . . . . 11

1.5 Publications . . . . . . . . . . . . . . . . . . . 12

$\begin{array}{ll}\text { References } & 15\end{array}$

$\begin{array}{ll}\text { Papers } & 17\end{array}$

1 Vehicle Dynamics Platform, Experiments, and Modeling Aiming at $\begin{array}{lr}\text { Critical Maneuver Handling } & 19\end{array}$

1 Introduction . . . . . . . . . . . . . . . . . . . . 21

2 Experimental Equipment . . . . . . . . . . . . . . . . . . 21

3 Vehicle Modeling . . . . . . . . . . . . . . . . . . . . . . . 24

4 Test Scenarios . . . . . . . . . . . . . . . . . . . . . 27

5 Model Parameter Estimation . . . . . . . . . . . . . . . . 28

6 Model Validation and Analysis . . . . . . . . . . . . . . . 33

7 Conclusions . . . . . . . . . . . . . . . . . 34

References . . . . . . . . . . . . . . . . . . . . 39

2 Models and Methodology for Optimal Trajectory Generation in Safety$\begin{array}{ll}\text { Critical Road-Vehicle Maneuvers } & 41\end{array}$

1 Introduction . . . . . . . . . . . . . . . . . . . . . 43

2 Problem Formulation . . . . . . . . . . . . . . . . . 46

3 Modeling . . . . . . . . . . . . . . . . . . 47 
4 Optimal Control Problem . . . . . . . . . . . . . . . . . 54

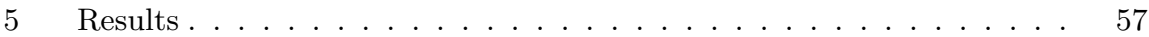

6 Discussion and Conclusions . . . . . . . . . . . . . . . 71

References ............................. 74

3 An Investigation of Optimal Vehicle Maneuvers for Different Road $\begin{array}{lr}\text { Conditions } & \mathbf{7 9}\end{array}$

1 Introduction . . . . . . . . . . . . . . . . . . . . . . 81

2 Modeling . . . . . . . . . . . . . . . . . . . 82

3 Optimal Control Problem . . . . . . . . . . . . . . . . . 85

$4 \quad$ Results . . . . . . . . . . . . . . . . . . . 87

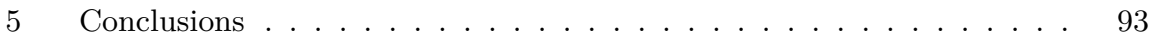

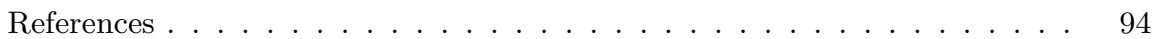

4 Towards Lane-Keeping Electronic Stability Control for Road-Vehicles 97

1 Introduction . . . . . . . . . . . . . . . . . . . . . . 99

2 Method .......................... 100

3 Modeling . . . . . . . . . . . . . . . . . . . . . . . 101

4 Optimal Control Problem . . . . . . . . . . . . . . . . . . . 103

$5 \quad$ Results . . . . . . . . . . . . . . . . . . 106

6 Discussion . . . . . . . . . . . . . . . . . . 111

7 Conclusions . . . . . . . . . . . . . . . . . . . . . 113

References . . . . . . . . . . . . . . . . . . . . . . 114

5 Analyzing Rollover Indices for Critical Truck Maneuvers $\quad 117$

1 Introduction . . . . . . . . . . . . . . . . . . . . . . . 119

2 Modeling of a Twin-Steer Truck . . . . . . . . . . . . . . . . . . 120

3 Rollover Indices . . . . . . . . . . . . . . . . . . . . . . . . . . . . . . . 124

4 Optimal Control Problem . . . . . . . . . . . . . . . . . . 127

$5 \quad$ Results and Discussion . . . . . . . . . . . . . . . . . . . . 127

6 Conclusions . . . . . . . . . . . . . . . . . . . . . . 134

References . . . . . . . . . . . . . . . . . . . . 135

6 Implications of Path Tolerance and Path Characteristics on Critical $\begin{array}{lr}\text { Vehicle Maneuvers } & 137\end{array}$

1 Introduction . . . . . . . . . . . . . . . . . . . . . . . . . . . 139

2 Maneuvers . . . . . . . . . . . . . . . . . . . . . . . 141

3 Vehicle models . . . . . . . . . . . . . . . . . . . . . . . . . 144

4 Model analysis . . . . . . . . . . . . . . . . . . . . 150

5 Optimal control problem formulation . . . . . . . . . . . . . . 151

6 Results . . . . . . . . . . . . . . . . . 156

7 Discussion . . . . . . . . . . . . . . . . . . . 172

8 Conclusions . . . . . . . . . . . . . . . . . . . 174

References . . . . . . . . . . . . . . . . . 175 


\section{Introduction}





\section{Introduction}

Vehicle dynamics modeling and simulation has become more important and valuable than ever for the vehicular industry. As manufacturers are pushing their research and development toward more simulation based and computer aided methods, while on-board electronic systems at the same time see an incredible fast growth in complexity, a comprehensible know-how of the aforementioned topics is essential to keep up with the market competitors. Vehicle components, characteristics, and control system algorithms are nowadays evaluated extensively in software environments before real world testing. However, as vehicles turn into systems of higher complexity and with new on-board control systems given the opportunity to exploit the extensive progress in sensor, actuator, and electronics technology, the design engineers are given a difficult task. The challenge lies in how to utilize this new technology to its fullest, delivering the best possible performance given certain objectives and predefined constraints. Here, optimization methods in different forms can be a tremendous asset. Whether it is a control input sequence or a system of various components, if the task objective and limitations are well defined, a definite best solution exists. Then it is of course beneficial to use tools that can find these optimal solutions, and do it quickly, compared to an iterative design process.

Although vehicle dynamics modeling has been studied extensively throughout the last century, new light on the subject is needed as optimization based analysis and implementations are considered. Even though the modeling approaches are similar, careful considerations must be taken when selecting model configurations. Where simulation models have been successfully evaluated within a certain maneuvering envelope, optimization methods might find solutions beyond these limits, exploiting loopholes or weaknesses in the model, ultimately resulting in unrealistic and probably too optimistic solutions. An intricate and devious task here is to comprehend the implication of the model complexity in the optimization 
framework, for different driving scenarios, objectives, and constraints. The most appropriate vehicle-model configuration and problem structure will certainly vary with the demands and restrictions coupled to the task at hand.

This thesis investigates topics inspired by the design challenges and problematic development choices emerging from the subjects discussed earlier in this section. Model configurations and approaches, for road vehicle dynamics, are evaluated in safety-critical maneuvering scenarios. This is partly done with real-world vehicle tests, but the main focus lies within optimal-control based studies.

\subsection{Motivating Factors and Development Trends}

The ever growing vehicle-transportation fleet sees increasing demands on vehicle and traffic safety, both from the consumer point-of-view (Koppel et al., 2008) as well as in shape of more stringent legislation requirements. Passive safety has seen a lot of refinements over the last decades, such as seat belts and structural deformation zones, mostly concentrated toward minimizing injury in the event of an accident. The aim of electronic and active safety systems, on the other hand, is often to prevent the accident from occurring in the first place. These systems have also experienced a vast improvement and a more extensive area of application recently, much owing to the technology advancements seen globally. However, safety is not the only driving force. Cost, efficiency, comfort, as well as convenient means of transportation, are all contributing factors pushing research and development forward. One example is the strive toward automated driving, receiving plenty of attention from academia, industry, and media lately.

\subsubsection{Toward Autonomous Driving}

In recent years, autonomous driving has emerged from a futuristic research topic, to be regarded as an enticing development direction within the transportation segment. A number of various self-driving vehicle concepts has already been showcased by research institutions and manufacturers, for example participants in the Grand Challenge and the Urban Challenge competitions conducted by DARPA (Buehler et al., 2007, 2009), Google's self-driving vehicles (Guizzo, 2011), Stanford's autonomous "at-the-limit" Audi TTS (Kapania and Gerdes, 2015), just to mention a few successful examples demonstrating what the future of transportation might offer. However, these systems are often heavily equipped vehicles under extensive engineering supervision ahead of, during, and/or after the driving mission, and might not be financially nor practically suitable for the consumer market in their current configurations. More consumer friendly systems are Tesla's Autopilot (Ackerman, 2015), already on the market, Volvo's DriveMe project (Laursen, 2013), with a customer trial period starting in 2017, and the selfparking systems several manufacturers nowadays offer. These systems categorize more toward automated driving modes, that can be engaged under certain driving circumstances or in specified environments. To distinguish between these different automated systems, and to provide a terminology facilitating 
discussions and collaborations on the subject, SAE published the standard J3016 (SAE J3016) in 2014. Automated driving systems were here classified into six different categories; from "No Automation" to "Full Automation".

An extensive review of the challenges and possibilities that come with future autonomous vehicles, focusing on the vehicle systems, is presented in (Gordon and Lidberg, 2015). One of many discussed subjects is the shape of the nearfuture vehicle systems. A fully-autonomous vehicle fleet is probably not feasible for a long time, except for enclosed environments such as work sites. The vehicle systems are more likely to see a gradually progression, starting with more versatile active-safety systems and partially autonomous systems with an option to fall back on the human driver when needed. However, regardless of the extent of automation of the system, it must be able to handle a number of critical events, rather than relying on the human driver to handle quick control hand-overs where an immediate maneuvering action is required to avoid an accident. Since, as pointed out in (Gordon and Lidberg, 2015), the general driver needs a certain workload to maintain focus and perform well, he or she will be in need of assistance if either under- or overloaded. As automated driving is introduced, especially if in an iterative and progressive manner, a considerable amount of this workload is removed, leaving the driver understimulated, with an increased response time as a result. Thus, the demands on safety systems and their capabilities increase drastically.

\subsubsection{Emerging Active-Safety Systems}

Since the introduction of electronic safety systems with anti-lock braking systems (ABS) (Genta and Morello, 2009) and electronic stability control (ESC) (Van Zanten, 2002) in the 1970's and 1980's, a lot has changed in terms of capabilities and requirements. From early systems only relying on driver intentions and input, through steering wheel, brake pedal, and throttle actuation, to now having enough available information to analyze the surrounding environment, analyze the situation, and make active decisions on its own. The additional information comes from the technological advancements earlier mentioned, in shape of new and improved sensors, more powerful computational hardware, as well as shared information from vehicle-to-vehicle and vehicle-to-road-side communication, (Faezipour et al., 2012). Also actuator components have seen a lot of progress, where for example electronic steering systems, often intended for self-parking applications, become more popular in passenger cars. These types of control actuators are of course also a necessity when automated driving functions are introduced. However, the increased controllability in combination with the additional information, offers tremendous opportunities for future safety systems, with proactive automated control algorithms preventing harmful accidents.

As already touched upon in the previous section, by adding more autonomous functions or modes in vehicles, the requirements on the safety systems change. If the driver is not engaged in the driving, his/her actions can be irrational and dangerous in a sudden safety-critical situation. This can introduce issues, especially when the actuators (such as steering wheel and braking system) have mechanical connections, where the safety system must handle driver control 
actions that in worst case counteracts the electronic systems intentions. With various by-wire systems (steer-by-wire, brake-by-wire, etcetera), this can be circumvented, allowing the safety system to work without the human disturbance. Though, this puts a huge responsibility, both technically and legally, on the vehicle system, the system engineers, and the manufacturers.

When safety systems become more versatile, handling previously never considered situations, different approaches with inspiration from alternative areas might be of great benefit. For example, (Voser et al., 2010) suggest that maneuvering inspired by race and rally car drivers could be exploited in future systems, and presents a drifting controller for a rear-wheel driven vehicle. Similarly, a handbrake drifting controller is developed in (Velenis, 2011). These are just two examples from a vast and growing range of research investigations studying more extreme race/rally inspired maneuvering approaches with safety applications in mind.

\subsection{Optimal Control for Vehicle Maneuvers}

The use of optimization technologies as a tool in the development of vehicle control systems has been proven to be beneficial in several aspects. The optimization algorithms could be implemented and utilized in the on-board control systems, while solutions to optimization problems obtained offline could be of great value in itself, as it can provide insight to certain phenomena or be used as inspiration for control strategies, as stated in (Sharp and Peng, 2011). Optimization tools can also be an asset in the evaluation process, providing valuable understanding of the performance potential for different system configurations, or choice of model parameters. Several studies have been performed for this purpose, for example in (Sundström et al., 2010) safety-critical situations for a maximum entry-speed formulation are studied, and in (Yang et al., 2012) a minimum lateral-deviation problem is considered. Similar tools have also seen an extensive use in more performance oriented applications, often with a minimum-time objective. Casanova et al. (2000) evaluated vehicle performance, based on maneuvering time, for various vehicle parameters, and in (Kelly and Sharp, 2010) a method for minimizing lap time of a race car was presented.

Even though optimization methods can be considered a powerful tool, the solution to an optimization problem will always rely on the problem formulation, that is, the choice of optimization objectives and model configurations. Thus, model validity plays an even more crucial role, compared to in simulation, where a congruent model only is necessary in the areas of intended operation. In optimization, however, it becomes imperative to ensure that inconsistencies or invalid model behavior are not within reach for the solver, to prevent the solution from utilizing these shortcomings.

\subsection{Summary of papers}

The main topics in this thesis consider road-vehicle maneuvering in safetycritical driving scenarios, where the vehicle typically is forced to utilize the outer 
limits of its maneuvering envelope. With an aim toward future on-board active safety-systems and automated vehicles, the focus lies on vehicle modeling and problem formulations for such applications. For this purpose, optimal control methods have been used as a tool to generate critical maneuvers for different vehicle models and problem formulations, to analyze the implications the various configurations have. These topics are investigated to various degrees in the included papers, whose content and contributions are briefly summarized below.

\section{Paper 1}

Kristoffer Lundahl, Jan Åslund, and Lars Nielsen. Vehicle Dynamics Platform, Experiments, and Modeling Aiming at Critical Maneuver Handling. Technical Report LiTH-ISY-R-3064. Department of Electrical Engineering, Linköping University, SE-581 83 Linköping, Sweden, 2013.

In the first paper, the ability low-complexity vehicle models, suitable for on-board applications, have in terms of representing the vehicle dynamics is investigated. Different model configurations, based on the single-track model, are evaluated against measurement data gathered with the vehicle dynamics testbed depicted in Figure 1.1. The study is focusing on the vehicle's lateral dynamics during aggressive, or critical, maneuvering. The paper concludes that the low-complexity models studied here, can predict the vehicle's lateral behavior for the most essential variables surprisingly well, even for rapid and critical maneuvers.

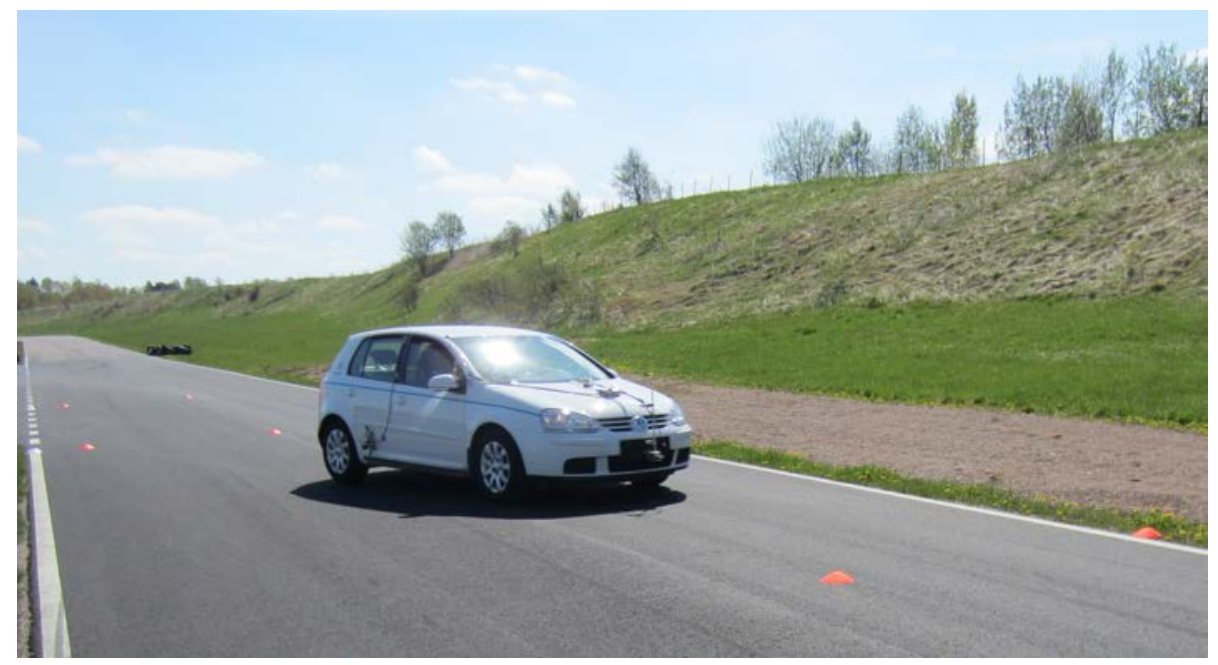

Figure 1.1: The sensor-equipped vehicle, presented in Paper 1, in action at the test track. 


\section{Paper 2}

Karl Berntorp, Björn Olofsson, Kristoffer Lundahl, and Lars Nielsen. Models and Methodology for Optimal Trajectory Generation in SafetyCritical Road-Vehicle Manoeuvres. Vehicle System Dynamics, 52(10): 1304-1332, 2014.

Paper 2 begins to investigate different vehicle and tire model configurations in critical maneuvers. For this purpose, a methodology for solving optimization problems in vehicle maneuvering is presented, and used for solving minimum-time optimization problems for different maneuvers, one being a hairpin turn similar to the maneuver shown in Figure 1.2. The optimal solutions show that the choice of vehicle model has a significant influence on the optimal control inputs. However, similarities are obtained for several important high-level variables, such as the path, yaw moment, and body-slip. This suggests that even the less complex models could be used for certain purposes in on-board safety systems, offering a reduced computational effort but resulting in similar results as the more complex model configurations.

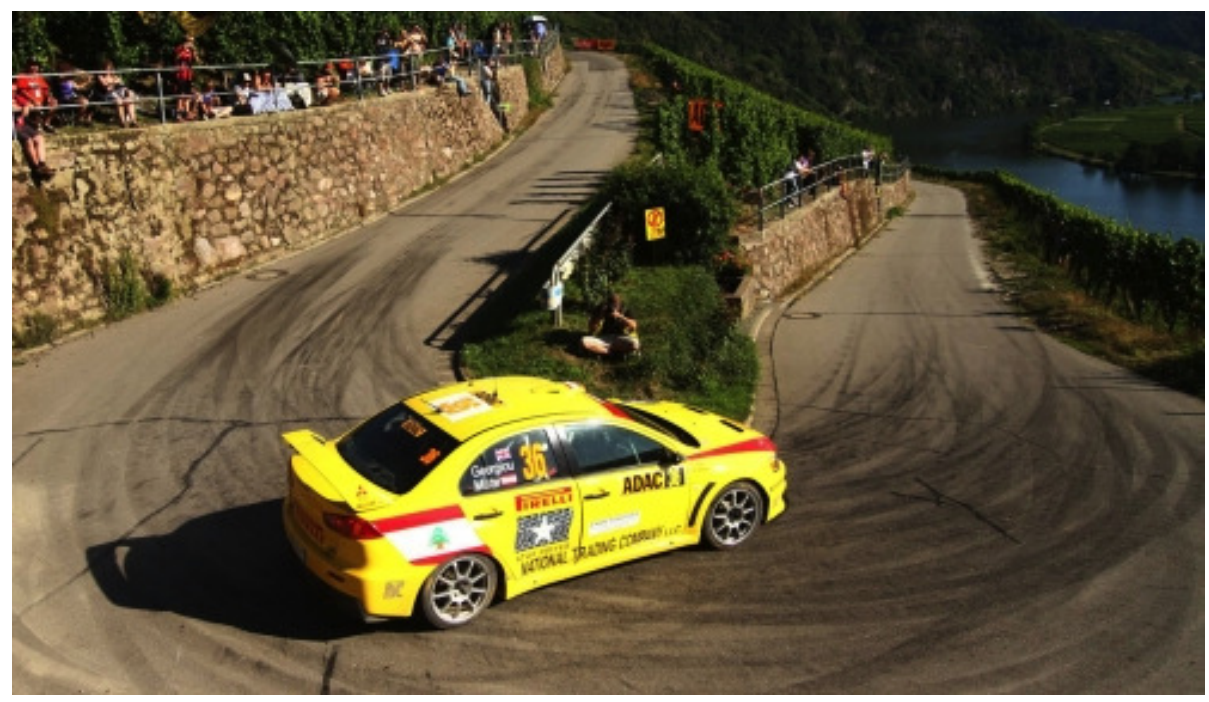

Figure 1.2: An example of a hairpin turn, similar to one of the maneuvers studied in Paper 2. Photo courtesy of RallySportLive.

\section{Paper 3}

Björn Olofsson, Kristoffer Lundahl, Karl Berntorp, and Lars Nielsen. An Investigation of Optimal Vehicle Maneuvers for Different Road Conditions. 7th IFAC Symposium on Advances in Automotive Control. Tokyo, Japan, 2013.

Paper 3 acknowledges the importance road and weather variations can have on the vehicle dynamics, by analyzing the influence different road-surface conditions 
have on the optimal maneuvering. Tire models representing asphalt, snow, and ice, composed based on established models and published experimental data, are employed in optimal control problems using the methodology from Paper 2. These are applied to a hairpin turn, similar to the road segment in Figure 1.3. The obtained result show that fundamental differences appear in the control strategies for the different road conditions, while, for example, the driving path throughout the maneuver is similar for all surface models.

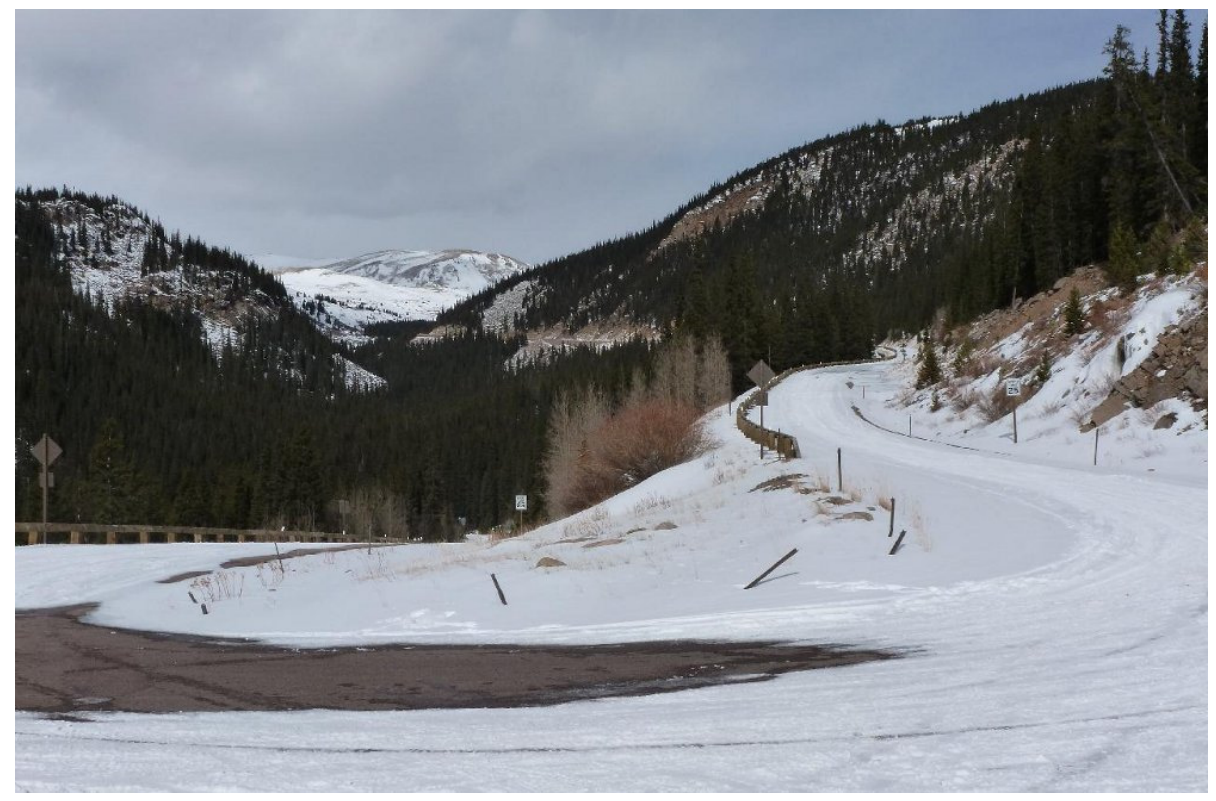

Figure 1.3: A snow covered hairpin turn, similar to the maneuvers studied in Paper 3. Photo courtesy of redlegsrides.blogspot.com.

\section{Paper 4}

Kristoffer Lundahl, Björn Olofsson, Karl Berntorp, Jan Åslund, and Lars Nielsen. Towards Lane-Keeping Electronic Stability Control for Road-Vehicles. 19th IFAC World Congress. Cape Town, South Africa, 2014.

The control strategies used by traditional electronic safety-systems might not be the best option when information about the surrounding environment becomes available. This is investigated in Paper 4, where the road/lane boundaries are known and form the confined space in which the vehicle must stay. Traditional stability control typically applies a yaw moment using the brakes to aid turning, for example, when over-speeding into a road turn. The best possible control actions using this traditional strategy is compared to the optimal strategy, where all wheels are accessible for braking (regardless of how the resulting yaw moment is directed). The optimal strategy clearly prioritizes reducing the speed quickly, in contrast to the traditional approach focusing more on yaw-moment control. 
The benefit of the optimal strategy is the ability to handle significantly higher entry velocities.

\section{Paper 5}

Kristoffer Lundahl, Chih Feng Lee, Erik Frisk, and Lars Nielsen. Analyzing Rollover Indices for Critical Truck Maneuvers. SAE International Journal of Commercial Vehicles, 8(1):189-196, 2015.

Vehicle rollover is a serious concern for heavy trucks. To prevent this from occurring, for example with active safety systems or fully autonomous driving, it is necessary to describe the phenomenon to a sufficient degree. The implications of different rollover indices with respect to the vehicle maneuvering is therefore studied in Paper 5. In particular, a very intuitive and simple lateral-acceleration based index is compared to a more physical load-transfer based index, loosely depicted to the left and right in Figure 1.4. The method of comparison is based on an optimal control approach, where rollover prone driving scenarios are generated. If a simple lateral-acceleration based index is used, the threshold indicating rollover will vary between stationary and highly dynamic maneuvers. Thus, to handle all scenarios, a very conservative limit has to be chosen. However, this can constrain the vehicle's maneuverability too much in many scenarios. Instead, using sets of predetermined situation-specific thresholds could be an alternative to overcome this.

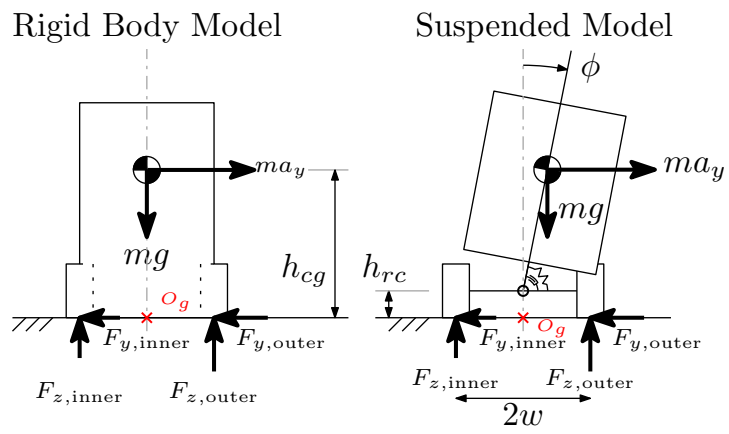

Figure 1.4: To the left, a rigid vehicle model that is implied by the lateralacceleration based rollover index. To the right, a vehicle model incorporating roll dynamics, which in turn affects the lateral load transfer and therefore is an important aspect when rollover is investigated.

\section{Paper 6}

Kristoffer Lundahl, Erik Frisk, and Lars Nielsen. Implications of Path Tolerance and Path Characteristics on Critical Vehicle Maneuvers. Submitted for journal publication.

In complex autonomous-driving systems, the motion control can be structured in multiple subsystems that handles different tasks, as for example depicted in Figure 1.5. In Paper 6, path following based on optimal control formulations for 
on-the-limit maneuvering is studied. In particular, the interplay between vehicle model requirements and path characteristics and tolerances is investigated. Results quantifying how the model complexity requirements depend on, for example, path deviation tolerance, path-curvature rate of change, and road surface friction, are presented. These findings can provide valuable guidance when designing real-time path following where it is necessary to handle a wide range of path characteristics.

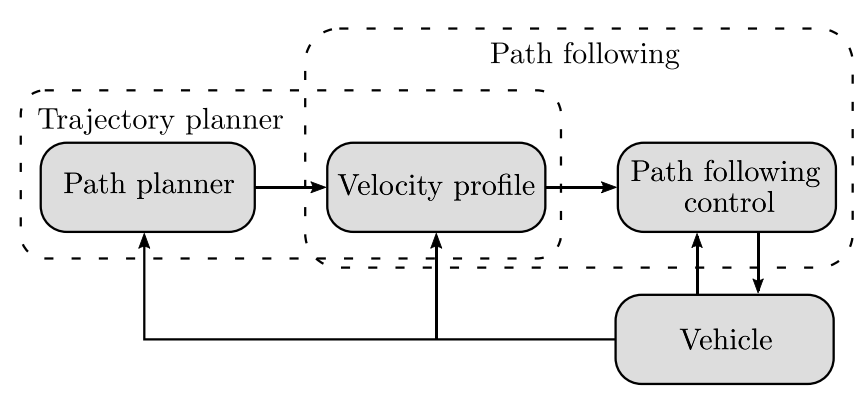

Figure 1.5: Example of a path-planning and path-following system layout.

\subsection{Outlook and Future Work}

As indicated in the introduction, much of the research content in this thesis aims toward future on-board vehicle-safety applications. Assuming information such as maps of road topology, upcoming traffic situations, shared details about the road conditions (for example road-surface friction), etcetera, are all available through a continuous data flow to the vehicle. Then, more versatile safety algorithms could be employed in the vehicles. However, it is unrealistic to believe that the same optimization formulations, routines, and algorithms used in this thesis can be expected to run in real-time with on-board computational hardware within a near future. Thus, it is necessary to simplify the problem, for example, by reducing the complexity of the models representing the vehicle characteristics. It is here the results in this thesis can be particularly valuable.

With the future safety systems still in mind, an obvious continuation of the work in this thesis would be on the implementation of "on-board friendly" control algorithms. This involves formulating problems that are accurate enough to provide useful and relevant maneuvering guidance, while at the same time deliver the results in real-time within a tight time frame. For this, several subtopics have to be acknowledged, such as optimization algorithms and formulations and vehicle modeling for both vehicle control and optimization/planning operations. Furthermore, when these types of applications are considered, robustness is always of a high priority. Thus, knowledge about the system's or model's sensitivity to parameter uncertainties and estimation disturbances could be valuable. Sensitivity analysis of, for example, optimal maneuvering trajectories, provides clear measures on how different parameters affect the vehicle characteristics, trajectory, or limitations in certain critical maneuvers. These types of studies can 
also complement some of the vehicle modeling studies here, by indicating which vehicle properties are the most important ones in different driving scenarios.

A slightly different topic, which has come to attention at several occasions, is human driver analysis and comparison to the computed optimal maneuvering. For example, in Paper 2, analogies with professional race and rally drivers are made when analyzing the time-optimal solutions. This would be interesting to analyze further with proper data provided. The direct benefit and application in vehicle safety systems might not be obvious, but it could result in interesting and valuable knowledge about the human-vehicle interactions, and how this can be simulated by optimal maneuvering algorithms.

\subsection{Publications}

The following papers have been published.

\section{Journal papers}

- Karl Berntorp, Björn Olofsson, Kristoffer Lundahl, and Lars Nielsen. Models and Methodology for Optimal Trajectory Generation in SafetyCritical Road-Vehicle Manoeuvres. Vehicle System Dynamics, 52(10):1304$1332,2014$.

- Kristoffer Lundahl, Chih Feng Lee, Erik Frisk, and Lars Nielsen. Analyzing Rollover Indices for Critical Truck Maneuvers. SAE International Journal of Commercial Vehicles, 8(1):189-196, 2015.

\section{Submitted}

- Kristoffer Lundahl, Erik Frisk, and Lars Nielsen. Implications of Path Tolerance and Path Characteristics on Critical Vehicle Maneuvers.

\section{Conference papers}

- Kristoffer Lundahl, Jan Åslund, and Lars Nielsen. Investigating Vehicle Model Detail for Close to Limit Maneuvers Aiming at Optimal Control. 22nd International Symposium on Dynamics of Vehicles on Roads and Tracks. Manchester, United Kingdom, 2011.

- Karl Berntorp, Björn Olofsson, Kristoffer Lundahl, Bo Bernhardsson, and Lars Nielsen. Models and Methodology for Optimal Vehicle Maneuvers Applied to a Hairpin Turn. 2013 American Control Conference. Washington D.C., USA, 2013.

- Kristoffer Lundahl, Karl Berntorp, Björn Olofsson, Jan Åslund, and Lars Nielsen. Studying the Influence of Roll and Pitch Dynamics in Optimal Road-Vehicle Maneuvers. 23nd International Symposium on Dynamics of Vehicles on Roads and Tracks. Qingdao, China, 2013. 
- Björn Olofsson, Kristoffer Lundahl, Karl Berntorp, and Lars Nielsen. An Investigation of Optimal Vehicle Maneuvers for Different Road Conditions. 7th IFAC Symposium on Advances in Automotive Control. Tokyo, Japan, 2013.

- Kristoffer Lundahl, Björn Olofsson, Karl Berntorp, Jan Åslund, and Lars Nielsen. Towards Lane-Keeping Electronic Stability Control for RoadVehicles. 19th IFAC World Congress. Cape Town, South Africa, 2014.

- Kristoffer Lundahl, Chih Feng Lee, Erik Frisk, and Lars Nielsen. PathDependent Rollover Prevention for Critical Truck Maneuvers. 24rd International Symposium on Dynamics of Vehicles on Roads and Tracks. Graz, Austria, 2015.

\section{Technical reports}

- Kristoffer Lundahl, Jan Åslund, and Lars Nielsen. Vehicle Dynamics Platform, Experiments, and Modeling Aiming at Critical Maneuver Handling. Technical Report LiTH-ISY-R-3064. Department of Electrical Engineering, Linköping University, SE-581 83 Linköping, Sweden, 2013. 



\section{References}

E Ackerman. Tesla model s. summer software update will enable autonomous driving. IEEE Spectrum Cars That Think, 2015.

Martin Buehler, Karl Iagnemma, and Sanjiv Singh. The 2005 DARPA grand challenge: the great robot race, volume 36. Springer Science \& Business Media, 2007.

Martin Buehler, Karl Iagnemma, and Sanjiv Singh. The DARPA Urban Challenge: Autonomous vehicles in city traffic, volume 56. springer, 2009.

D. Casanova, R.S. Sharp, and P. Symonds. Minimum time manoeuvring: The significance of yaw inertia. Vehicle System Dynamics, 34(2):77-115, 2000.

Miad Faezipour, Mehrdad Nourani, Adnan Saeed, and Sateesh Addepalli. Progress and challenges in intelligent vehicle area networks. Commun. ACM, 55(2):90-100, February 2012.

Giancarlo Genta and Lorenzo Morello. The automotive chassis, volume 1. Springer, 2009.

T.J. Gordon and M. Lidberg. Automated driving and autonomous functions on road vehicles. Vehicle System Dynamics, 53(7):958-994, 2015.

Erico Guizzo. How google's self-driving car works. IEEE Spectrum Online, October, 18, 2011.

Nitin R. Kapania and J. Christian Gerdes. Design of a feedback-feedforward steering controller for accurate path tracking and stability at the limits of handling. Vehicle System Dynamics, 53(12):1687-1704, 2015. 
D. P. Kelly and R. S. Sharp. Time-optimal control of the race car: a numerical method to emulate the ideal driver. Vehicle System Dynamics, 48(12):1461$1474,2010$.

Sjaanie Koppel, Judith Charlton, Brian Fildes, and Michael Fitzharris. How important is vehicle safety in the new vehicle purchase process? Accident Analysis \& Prevention, 40(3):994 - 1004, 2008.

Lucas Laursen. Volvo to test self-driving cars in traffic. IEEE Spectrum Cars That Think, 2013.

SAE J3016. Taxonomy and definitions for terms related to on-road motor vehicle automated driving systems. Technical report, Society of Automotive Engineers, Warrendale, USA, 2014.

R. S. Sharp and Huei Peng. Vehicle dynamics applications of optimal control theory. Vehicle System Dynamics, 49(7):1073-1111, 2011.

Peter Sundström, Mats Jonasson, Johan Andreasson, Annika Stensson Trigell, and Bengt Jacobsson. Path and control optimisation for over-actuated vehicles in two safety-critical maneuvers. In 10th Int. Symp. on Advanced Vehicle Control (AVEC), Loughborough, United Kingdom, 2010.

Anton T Van Zanten. Evolution of electronic control systems for improving the vehicle dynamic behavior. In Proceedings of the 6th International Symposium on Advanced Vehicle Control, pages 1-9, 2002.

Efstathios Velenis. FWD vehicle drifting control: The handbrake-cornering technique. In IEEE Conf. on Decision and Control (CDC), pages 3258-3263, Orlando, FL, 2011.

Christoph Voser, Rami Y Hindiyeh, and J Christian Gerdes. Analysis and control of high sideslip manoeuvres. Vehicle System Dynamics, 48(S1):317-336, 2010.

Derong Yang, T.J. Gordon, B. Jacobson, and M. Jonasson. Quasi-linear optimal path controller applied to post impact vehicle dynamics. Intelligent Transportation Systems, IEEE Transactions on, 13(4):1586-1598, 2012. 
Papers 



\section{Papers}

The articles associated with this thesis have been removed for copyright reasons. For more details about these see:

http://urn.kb.se/resolve?urn=urn:nbn:se:liu:diva-127798 
Linköping studies in science and technology. Dissertations.

Division of Vehicular Systems

Department of Electrical Engineering

Linköping University

No. 1 Magnus Pettersson, Driveline Modeling and Control, 1997

No. 2 Lars Eriksson, Spark Advance Modeling and Control, 1999

No. 3 Mattias Nyberg, Model Based Fault Diagnosis: Methods, Theory, and Automotive Engine Applications, 1999

No. 4 Erik Frisk, Residual Generation for Fault Diagnosis, 2001

No. 5 Per Andersson, Air Charge Estimation in Turbocharged Spark Ignition Engines, 2005

No. 6 Mattias Krysander, Design and Analysis of Diagnosis Systems Using Structural Methods, 2006

No. 7 Jonas Biteus, Fault Isolation in Distributed Embedded Systems, 2007

No. 8 Ylva Nilsson, Modelling for Fuel Optimal Control of a Variable Compression Engine, 2007

No. 9 Markus Klein, Single-Zone Cylinder Pressure Modeling and Estimation for Heat Release Analysis of SI Engines, 2007

No. 10 Anders Fröberg, Efficient Simulation and Optimal Control for Vehicle Propulsion, 2008

No. 11 Per Öberg, A DAE Formulation for Multi-Zone Thermodynamic Models and its Application to CVCP Engines, 2009

No. 12 Johan Wahlström, Control of EGR and VGT for Emission Control and Pumping Work Minimization in Diesel Engines, 2009

No. 13 Anna Pernestål, Probabilistic Fault Diagnosis with Automotive Applications, 2009

No. 14 Erik Hellström, Look-ahead Control of Heavy Vehicles, 2010

No. 15 Erik Höckerdal, Model Error Compensation in ODE and DAE Estimators with Automotive Engine Applications, 2011

No. 16 Carl Svärd, Methods for Automated Design of Fault Detection and Isolation Systems with Automotive Applications, 2012.

No. 17 Oskar Leufvén, Modeling for Control of Centrifugal Compressors, 2013.

No. 18 Christofer Sundström, Model Based Vehicle Level Diagnosis for Hybrid Electric Vehicles, 2014. 
No. 19 Andreas Thomasson, Modeling and control of actuators and co-surge in turbocharged engines, 2014.

No. 20 Emil Larsson, Model Based Diagnosis and Supervision of Industrial Gas Turbines, 2014.

No. 21 Andreas Myklebust, Dry Clutch Modeling, Estimation, and Control, 2014.

No. 22 Tomas Nilsson, Optimal Engine Operation in a Multi-Mode CVT Wheel Loader, 2015.

No. 23 Daniel Jung, Diagnosability Performance Analysis of Models and Fault Detectors, 2015.

No. 24 Martin Sivertsson, Optimal Control of Electrified Powertrains, 2015.

No. 25 Peter Nyberg, Evaluation, Generation, and Transformation of Driving Cycles, 2015. 